\title{
HIASAN KEMUNCAK BANGUNAN
}

-Oleh : Djoko Soekiman

Apabila kita berkunjung ke kota-kota di Indonesia pertama-tama yang menarik perhatian kita adalah bentuk-bentuk bangunan rumah penduduk.

Berdasarkan macam-macam bentuk atap rumah, masing-masing diberi nama menurut gayanya sendiri, di Jawa misalnya ada yang dinamakan atap joglò, atap limasan, tajug, kampung dan sebagainya. Di Minangkabau rumah gadang mempunyai bentuk atap khusus yang berbeda dengan bangunan meunasah dari Aceh. Tegasnya nenek moyang Indonesia telah mewariskan kepada kita beraneka macam bentuk atap rumah, masing-masing dengan ciri khusus, dan kesemuanya memiliki keindahan tersendiri. Bentuk atap bangunan rumah kampung yang di Jawa merupakan bangunan rumah yang paling sederhana misalnya, mempunyai keindahan tersendiri di tengah-tengah alam Indonesia yang indah permai. Cobalah pembaca sekali-sekali mengamati pondok rakyat di kaki Gunung Merapi, Semeru atau Tangkubanperahu di pagi hari, sungguh menakjubkan! Rumah beratap kampung di selasela rindangnya rumpuǹ bambu atau pepohonan di lereng bukit yang hijau dengan tiang-tiang gantungan sangkar burung memberi kesan kedamaian dan kebahagiaan penghuninya, lebih-lebih di tingkah suara kokok ayam atau kambing yang mengembik, súngguh mempesona!

Akan hal warna-warni cat, untuk pondok rakyat yang sederhana ini tidak menjadi soal, cukup warna alam (asli) dari material bangunan, misalnya anyaman bambu untuk dinding, rumbia untuk atap, kayu năngka untuk daun pintu atau tiang, dan sebagainya. Warna kehijauan tumbuh-tumbuhan dan aneka warna bunga-bungaan yang tumbuh di sekeliling rumah, sudah menjadikan serasinya keindahan sebagai keseluruhan.

Bentuk atap rumah merupakan ciri pokok untuk menyebutkan suatu gaya-(stijl) bangunan rumah di Indonesia. Di Junani dan Romawi kuna, yang kemudian banyăk diikuti di Eropa, orang menyebutkan gaya (stijl) suatu bangunan berdasarkan bentuk tiangnya, misalnya: gaya Doria, Ionia, Korinthia.

Pada kesempatan ini penulis akan mengupas tentang hiasan kemuncak bangunan, yaitu hiasan yang justru terletak di atas atap bangunan. 
Di Indonesia, khususnya Jawa, hiasan di atas atap rumah kurang mendapat tempat, kecuali pada bangunan-bangunan peribadatan (mesjid, gereja, pura/candi). Pada bangunan rumah Eropa rupa-rupanya hiasan kemuncak mendapat perhatian dan mempunyai arti tersendiri, baik dári sudut keindahan, status sosial, maupun kepercayaan.

Banyak rumah penduduk di Demak, Jawa Tengah, pada bubungan atapnya dihiasi dengan deretan lempengan teracotta yang diujudkan seperti gambar tokoh-tokoh wayang, berderet-deret (Jawa di simping atau hanya melukiskan tumbuh-tumbuhan) dengan gunungan tepat di tengah-tengah. Masing-masing lempengan teracotta tersebut dihiasi dengan mozaik pecahan-pecahan cermin, sehingga di siang hari memantulkan sinar gemerlapan. Hiasan atap rumah-rumah di Demak ini

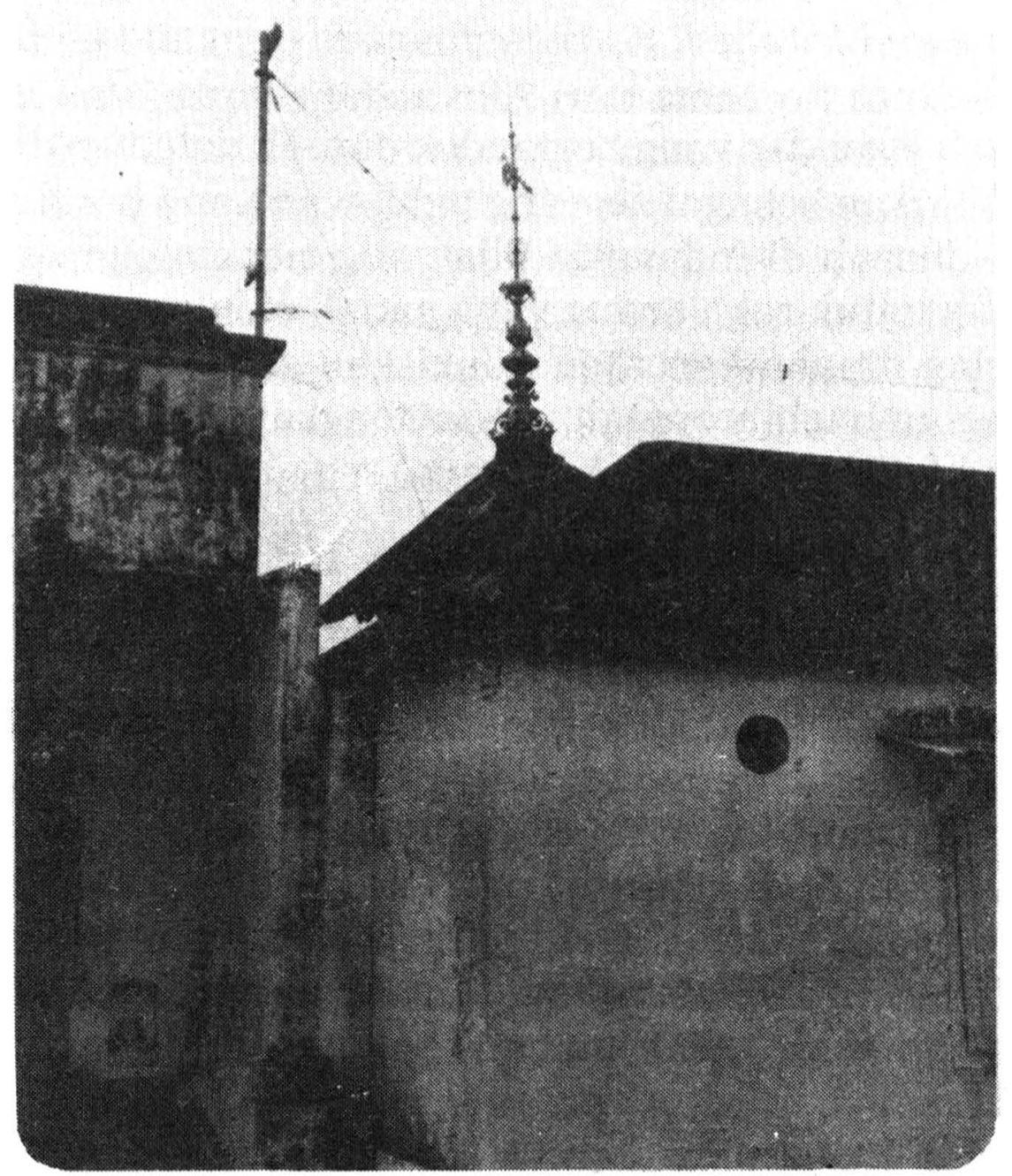

Kemuncak maøjid Suranatan, Surakarta, berhiaskan lukisan seekor ular, naga. 
jelas hanya berfungsi sebagai hiasan semata-mata, tanpa mempunyai arti symbolik tertentu.

Rumah-rumah Minangkabau berkemuncak seperti tanduk kerbau disamping hiasan pahatan pada bagian-bagian dindingnya seperti halnya rumah rakyat Batak Karo, sedang rumah Sa' dan Toraja di Su-lawesi penuh dengan pahatan pada serambi depan dengan perujudan kepala kerbau sebagai hiasan utama. Binatang kerbau merupakan binatang keramat pada masa Prasejarah Indonesia. Hiasan kepala kerbau kita dapatkan tersebar di seluruh Indonesia. Nenek moyang Indonesia dalam jaman Neolithicum sudah mengenal kerbau sebagai binatang ternak serta memujanya sebagai binatang keramat. Hal ini sampai sekarang ragam hias kepala kerbau atau hanya bagian tanduknya saja masih sering dipergunakan. sebagai hiasan, sering pula gambar bentuk kepala kerbau dan tanduknya hanya distilir saja. Tradisi menyebutkan bahwa hiasan kepala kerbau atau tanduknya adalah lambang dari kesuburan tanah, yang juga sebagai penolak rokh-rokh jahat. Sementara itu ada yang menyebutkan kerbau dengan tanduknya dihubungkan dengan bulan. Kepercayaan Mesir purba juga menyebutkan bahwa dewa Matahari Ra digambarkan dengan Lembu bertanduk panjang, sementara itu nama darı Alexander Agung, atau sskandar Zulkarnain berarti Iskandar yang bertanduk dua. Di dalam mythos Iskandar sering digambarkan sebagai seorang pahlawan yang bertanduk. Kerbau di beberapa daerah di Indonesia ada yang menganggap sebagai binatang tunggang untuk rokh orang yang sudah meninggal di akherat, karena itu sering dipahatkan atau dilukiskan sebagai ragam hias pada tenunan, bagian-bagian rumah, pada tongkat keramat kepala suku, alat-alat rumah tangga; dan sebagainya.

Kehadiran bangsa-bangsa Eropah di Indonesia sejak awal abad XVI mempengaruhi berbagai unsur kebudayaan, diantaranya juga dalam hal hiasan kemuncak bangunan rumah. Di negeri Belanda dahulu banyak rumah-rumah penduduk pada atapnya ditaruhkan windwijzer (penunjuk arah angin) yang juga berfungsi sebagai hiasan rumah. Negeri Belanda dengan iklimnya yang sangat keras, penunjuk arah angin dahulu mérupakan alat yang penting. Sehubungan dengan ini Washington Irving menulis tentang Nieuw Amsterdam di dalam A history of New Netherland, menyebutkan: ". . . . . Tiäp rumah di sini áda weerhaan yang sering kali tiap rumah menunjukkan ke arah yang tidak sama, karena itu biasanya orang mengarahkan pandangan ke rumah Gubernur, karena di sini orang beranggapan bahwa weerhaan di rumah gubernurlah yang benar. Tetapi baru lama kemudian mereka menge- 
tahui bahwa gubernur memang memelihara pembantu-pembantu yang mempunyai tugas tetap setiap hari memanjat atap untuk membenarkan arah ayam jago (penunjuk arah dengan gambar ayam jago) menuju ke arah yang betul ....'

Kemudian disusul Perancis, di sini juga banyak orang membuat penunjuk arah angin yang dipergunakan juga sebagai penghias kemuncak bangunan disebut girovettes, sedang senunjuk arah angin yang berputar-putar disebut,$\quad$ wir e-w i r e.

Dalam abad Tengah tidak semua orang dapat dengan sekehendak hati mẹmbuat windvaan, karena dikeluarkan ketentuan-ketentuan tertentu oleh penguasa, baik tentang bentuk maupun perwujudannya, misalnya seorang $\mathbf{r}$ i d d e $\mathbf{r}$ di atas puncak istananya dengan windvaan berbentuk seperti bendera, sedang untuk baanderheer menggunakan penunjuk arah berbentuk pesegi empat. Hal semacam ini kemudian lambat laun menjadi tanda lambang tertentu, misalnya ."bentuk pesegi" adalah hak pribadi lambang bannerets atau baanderheer, sedang untuk bangsawan/pejabat yang lebih rendah dengan bentuk bendera persegi empat panjang yang dipotong segi tiga pada ujungnya.

Dalam abad XV bangsawan-bangsawan tinggi menaruhkan pada ujung tongkat windvaan dengan hiasan mahkota (kroonj ada pula dengan hiasan berwarna keperakan dan pada sisi sudut persegi empat diisi dengan hiasan rozet, tetapi lazimnya diisi dengan lambang keluărga dari pemiliknya. Umumnya windvaan terbuat dari logam dengan warna-warna menyala yang dapat kelihatan dari tempat kejauhan, yang sangat disukai warna merah metalik, kemudian warna-warni, khususnya warna keemasan. Warna keemasan adalah warna yang mudah luntur, yang menjadi jelek, disebut stofgona yang sering disebut mort d'ore atau dood goud.

Ada pula warna warni hiasan ini yang dibuat dengan porselin atau teracotta.

Di Eropa sekarang khususnya di negeri Belanda hiasan kemuncak yang berupa windwijzer dengan bermacam-macam bentuknya, seringkali menunjukkan macam usaha atau pekerjaan pemiliknya, misalnya. lukisan jantera alat memintal (roda alat tenun) terdapat di kota Laren, gambar bajak (alat untuk membajak tanah/pada kemuncak gudang gandum di dekat Groningen, alat pencukur di atas rumah tukang cukur (di Maas tricht), sebuah sepatu besar di atas toko sepatu di Utrechtsestraat 48, Amsterdam. Lukisan binatang seperti kuda, sapi banyak digunakan untuk hiasan rumah petani. Para pelaut sering menggunakan 
windijzer dengan lukisan perahu penangkap ikan, perahu Viking (di Rotterdam).

Lukisan pada kemuncak rumah-rumah penduduk tersèut di atas barang tentu kecuali menunjukkan usaha atau pekerjaan pemiliknya serta untuk maksud keindahan bangunan, tidak mempunyai arti khusus lain (jadi gambar ikan di sini bukan dimaksudkan dengan kata Ichtus yang lazim diartikan lambang Kristus seperti yang akan diuraikan berikut, demikian halnya gambar ayam jago).

Gambar seorang prajurit, pemburu, nelayan, petani bahkan dewadewa dahulu seringkali juga dilukiskan, misalnya dewa laut Triton sedang meniup terompet terlukis di kemuncak bangunan stadhuis di Amsterdam (Prinsenhof). Dewi fortuna yaitu dewi keberuntungan, orang Belanda menyebut de Fortuin terpancang besar sekạli di Beschuit bakkerstoren di Wormer. Centauren dengan memakai topi helm Yunani kuno terdapat di Bergen (negeri Belanda Utara). Jelaslah kiranya hiasan-hiasan kemuncak bangunan rumah tersebut bukan sekedar pekerjaan hasil produksi tukang-tukang kayu di desa. Memang, boleh jadi di Eropah benda-benda tersebut hasil karya anak-anak petani atau nelayan untuk pengisi waktu luang pada malam musim winter yang lengang; tetapi di Indonesia hiasan kerbau atau tanduk kerbau seperti tersebut di atas mempunyai arti tersendiri yang mendalam. Cara pembuatan, peletakkan hiasan kepalá kerbau pada bangunanbangunan Batak atau di Sulawesi misalnya, menggunakan cara dan upacara-upacara khusus, pembuatannya tidak dikerjakan oleh sembarang orang, apalagi untuk sekedar iseng pengisi waktu. Para sesepuh desa dengan diiringi berbagai upacara dan mantera-mantera mengikuti peletakan kemuncak bangunan yang berupa bentuk kepala kerbau tersebut. Berbagai selamatan, tabu dan ritual menyertai peletakan kemuncak bangunan.

\section{II}

Tentang hiasan kemuncak bangunan sakral seperti masjid, gereja, pura atau candi mempunyai arti tersendiri, baik sebagai symbolik maupun kepercayaan dan keagamaan.

Kemuncak bangunan masjid di Jawa lazim disebut mustaka atau mustika mesjid. Sebelum atap kubah banyak digunakan seperti masa sekarang, di Indonesia bangunan mesjid sering mempergunakan atap tumpang (atap bersusur seperti meru). Pada kemuncak atap berbentuk meru inilah diletakkar mustaka masjid sebagai hiasan. Bentuk mustaka 
masjid lazimnya berupa mahkota yang distilir, sementara orang ada yang menyebutkan, bahwa hiasan itu bukan bentuk mahkota yang distilir, tetapi justru perujudan "lidah api" yang tersembur dari kepundan gunung (kata meru artinya gunung; merapi dari bahasa jawa kuno meru dan apui = gunung berapi). Dalam mitologi Hindu dan Yunani kuno diceri terakan bahwa kahyangan tempat tinggal para dewa terletak di gunung Mahameru untuk India, dạ untuk Yunani di gunung Olympus. Mythos semacam itu juga dikenal di Indonesia. Di kota-kota pulau jawa sekarang, banyak bangunan mesjid menggunakan atap meru dengan diberi kemuncak kubah kecil, kubah ini juga disebut mustaka atau mustika masjid. Lukisan bintang dan bulan sabit sering disertakan pada mustaka masjid yang berbentuk kubah. Pada malam hari lukisan bintang dan bulan sabit tersebut diterangi lampu, sehingga tampak jelas dari kejauhan.

Bangunan candi mempunyai hiasan kemuncak ratna, stupa atau kubus. Uraian tentang bentuk atap dan kemuncak candi tidak penulis perpanjangkan di sini, karena akan diulas lebih mendalam oleh penulis lain.

Hiasan bangunan kemuncak gereja setelah jaman Gothiek berakhir, tidak selalu berupa palang salib yang berat, tetapi dapat pula berupa tongkat yang runcing pada ujungnya, sebagai lambang menunjuk ke tempat satu arah tertinggi, yang Esa. Tongkat runcing di atas kemuncak gereja ini baik sekali untuk diisi penunjuk arah angin, yang sekaligus untuk meletakkan penangkal petir. Kecuali gereja juga bangunan-bangunan seperti balai kota atau bangunan besar lainnya juga dihias demikian. Gereja-gereja tertua yang menggunakan penunjuk arah 'angin seperti itu antara lain ialah di Perancis sejak tahun 1250, di negeri Belanda sejak abad XIV, di Inggris Kathedral Eckingham (di Sussex), dan yang terbagus terdapat di Inggris juga, yaitu di Ottery berasal dari tahun 1412, pada windvaan di gereja ini diletakkan peluit, sehingga apabila ada angin yang keras peluitnya berbunyi nyaring.

Gereja-gereja tua tersebut juga menggunakan hiasan ayam jantan untuk pengisi tongkat dan penunjuk arah mata angin. Sejak kapan binatang berkaki dua yang berujud ayam jago ini menjadi hiasan dan bertengger di atas bangunan-bangunan sacral dan profane tidak lagi je las. Dahulu orang menyebut Zo'on windvaan atau gallus (ayam jantan) sebagai hiasan ventilogium (penunjuk arah angin). Di Perancis pada Abad Tengah apabila para ksatria dalam berperang dapat menduduki sebuah benteng lawannya, pertama kali yang mereka lakukan ialah menancapkan banier berlukiskan ayam jantan pada dinding benteng, sebagai tanda bahwa benteng tersebut telah jatuh dan diduduki oleh 
bangsawan lain. Ayam jago adalah merupakan lambang Perancis pada waktu itu, seperti halnya singa untuk orang Belanda, jadi lukisan ayam jago ini sebagai lambang kemenangan, seolah-olah seperti ayam jantan berkokok "meneriakkan kemenangan" sesudah berlaga.

Sejak jaman Yunani kuno ayam jantan dinobatkan sebagai lambang kecerdasan, keberanian, suka berkelahi. Ayam jantan juga dianggap sebagai pengusir kegelapan dan rokh-rokh jahat yang sedang marah. Di dalam mitologi Yunani ayam jantan adalah lambang dewa Apollo, sebagai dewa matahari, karena itu diceriterakan dengan berkokoknya ayam jantan adalah sebagai pertanda datangnya siang dan lenyapnya kegelapan malam. Dengan berkokoknya ayam jantan rokhrokh jahat lari ketakutan, dengan demikian menurut ceritera, penduduk mengangkat ayam jago sebagai pelindung dari gangguan rokh jahat, dan meletakkan gambarnya di atas bubungan rumah. Masa kemudian dengan dikenalnya penangkal petir, juga dianggap sebagai pelindung dari sambaran petir. Kepercayaan seperti itu dahulu umum dikenal di daratan Eropa, sampai saat sekarang juga masih banyak dipersoalkan mengapa ayam jago menjadi pilihan utama.

Sebaliknya ayam jantan juga dianggap sebagai lambang kebakaran, diceriterakan oleh seorang penulis jaman Kaesar Nero yang bernama Petronius bahwa setelah Tremalchian męndengar kokok ayam, mulailah api berkobar-kobar menjilat seluruh kota Roma.

Di Rusia dahulu ayam jantan juga dipergunakan sebagai lambang, konon diceriterakan juga sebagai binatang korban untuk pendirian sebuah bangunan. Ayam jantan tersebut ditanam dalam lantai di bawah pintu masuk atau pintu darurat dimaksudkan sebagai pelindung. Di Yunani kuno dan di negeri-negeri Balkan, ayam jantan hidup-hidup ditanam di dalam liang di bawah lantai bangunan, maksudnya dengan berbuat demikian mereka berharap dapat perlindungan dewa-dewa dari segala gangguan dan marabahaya. Di dalam prasasti jawa kuno sering terbaca kalimat "aneteh ayam, mebantingaken hantiga" dalam rangka peresmian upacara pendirian sebuah bangunan candi di Jawa. Apakah hal semacam ini merupakan dasar-dasar persamaan kepercayaan?

Sampai saat sekarang masih banyak dipersoalkan mengapa lukisan ayam jantan justru banyak dipergunakan untuk menghias kemuncak menara-menara gereja. Sementara pendapat ada yang menghubungkan dengan sangkalan yang diucapkan Petrus: . . . . sebelum ayam jantąn berkokok engkau akan menyangkal Aku tiga kali(Matheus $2^{\text {b }}$. 34). 


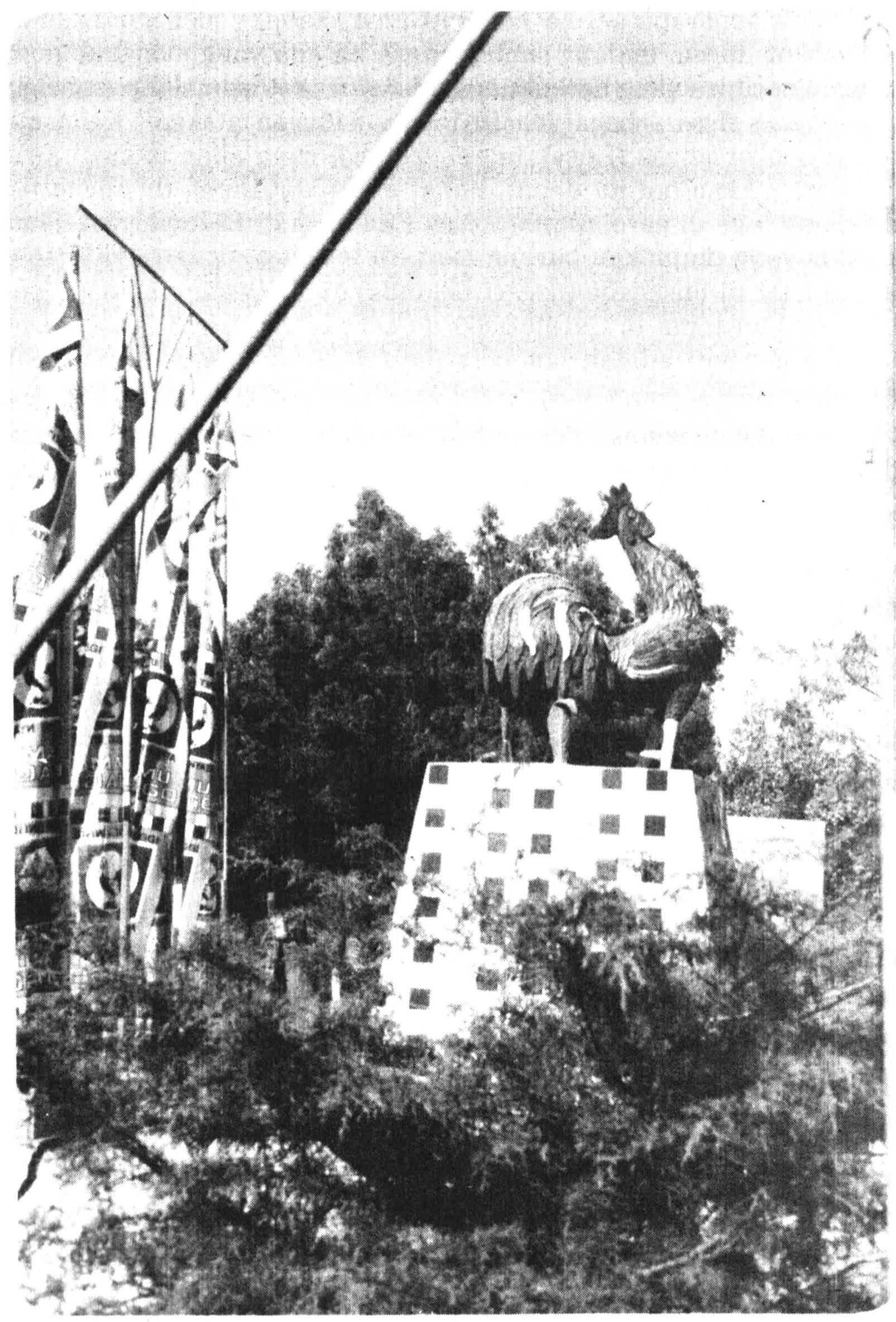

Patung ayam jago di Jurug, Surakarta. Ayam jago di sini adalah illan jamu cap jago, tidak ada sangkut pautnya dengan ayam jago di dalam makalah. 
Pada beberapa gereja Luther kadang-kadang menggunakan simbol seekor angsa, tentang simbol angsa ini ada yang menghubungkan dengan ceritera yang berhubungan dengan saat menjelang meninggatnya Johanes Huss, sebagai martir tahun 1415 menyatakan: "Kamu membakar seekor angsa (Huss), tetapi sesudah saya akan muncul swaan (Luther)". Akan hal ini dapat dilihat di Luther kapel, di Amsterdam, demikian juga di gereja Luther dari Zandaam di Leeuwarden. Simbol Kristus yang diujudkan burung merpati terdapat di Hersteld Apostolische kerk di Enschede (negeri Belanda) dan jangkar (lambang pengharapan) terdapat di Gereformeerde kerk di Zoutkamp (gem. Ulrum). Burung merpati adalah lambang jiwa Suci, di Yunani kuno disebut peristra.

Ikan dalam bahasa Yunani Kuno disebut Ichtus, adalah juga simbol dan bagian dari nama Kristus (Ichthus singkatan dàri Yesus Kristus Us Soter $=$ Yesus Kristus Tuhan Juru Selamat). İkan sebagai lambang Kristus, banyak kita ketemukan disamping lambang-lambang Kristus yang lain, seperti jangkar, Gembala Agung, palang salib, burung merpati, monogram-monogram INRI, Alfa dan Omega, dan sebagainya. Lambang-lambang dan monogram Kristus diketemukan orang dikatakomba-katakomba seperti di St. Calixtus dan sebagainya.

Demikianlah uraian singkat tentang hiasan kemuncak- yang kita dapatkan pada berbagai bangunan suci. Hiasan kemuncak pada bangunan-bangunan Eropa di Indonesia, baik yang berupa bangunan rumah, gedung-gedung pemerintahan maupun gereja-gereja, barang tentu adalah kelanjutan unsur pengaruh dari Eropa. 


\section{BAHAN BACAAN}

1. Eerde J.C. Van DeVolken van Nederlandsche Indie Uitg.

Maatschappij 'Elsevier" Amsterdam 1920.

2. 'Hoop, A.N. J. Th.a Th. yan der, Indonesische Siermotieven Uitg. Koninklijke Bataviaasch Genootschap van Kunsten en Wetenschappen, 1949.

3. Kruizinga, J.H. Ornamenten van huis en hof deel I, 1965.

4. Vrien, J. Stijlen in de bouwkunst, Amsterdam, N.V. Uitg, Mij Kosmos, 1948. 